\title{
Managerialism as a failing response to the care crisis
}

\section{Hoppania, Hanna-Kaisa}

Policy Press

2021-11-29

Hoppania , H-K , Olakivi , A , Zechner , M M \& Näre , L 2021, Managerialism as a failing response to the care crisis . in L L Hansen, H M Dahl \& L Horn (eds), A Care Crisis in the Nordic Welfare States? : Care Work, Gender Equality and Welfare State Sustainability . Transforming Care, Policy Press, Bristol , pp. 100-119.

http://hdl.handle.net/10138/338630

submittedVersion

Downloaded from Helda, University of Helsinki institutional repository.

This is an electronic reprint of the original article.

This reprint may differ from the original in pagination and typographic detail.

Please cite the original version. 
Always cite:

Hoppania, Hanna-Kaisa, Olakivi, Antero, Zechner, Minna \& Näre, Lena (2021). Managerialism as a failing response to the care crisis. In Lise Lotte Hansen, Hanne Marlene Dahl \& Laura Horn (Eds.), A Care Crisis in the Nordic Welfare States. Care Work, Gender Equality and Welfare State Sustainability (pp. 100-119). Bristol: Policy Press.

\section{Chapter 6. Managerialism as a Failing Response to the Care Crisis}

\section{Hanna-Kaisa Hoppania, Antero Olakivi, Minna Zechner, Lena Näre}

\section{Introduction}

For several decades now, elderly care services have been characterised by recurring crises in Finland. In 2006, a political scandal erupted when allegations became public of insufficient staff ratios in Koukkuniemi, the largest unit of institutional care for older adults in the Nordic countries at the time (Yle, 2006). In 2019, a scandal broke when the National Supervisory Authority for Welfare and Health (Valvira) ordered the closure of several care homes owned by private care companies due to severe neglect in the quality of care, and announced that they were investigating several complaints regarding deficiencies in elderly care (Valvira, 2019). Valvira's lawyer described the situation in the first care home as an 'acute crisis', which is why it was closed down immediately (Tiessalo, 2019). The situation was described as a 'care crisis' by the media, expert commentators and opposition politicians as well as the Regional State Administrative Agencies (AVI, 2020). 
Care crisis is understood here as referring to a situation in elderly care that has reached a critical phase in relation to the quality of care, also involving public concerns over the quality and conditions of care work. While a crisis is commonly understood as a temporary disruption, for many people in the world, such as older adults in poor health, a crisis can become a lasting, endemic condition. Nevertheless, when a crisis has been identified by central actors in the field, action needs to be taken.

In Finland, a common line of action is routinely suggested as a solution to the crisis of elderly care: improvements in the management of care. When developments and outcomes in elderly care turn into a media frenzy and draw public attention to deficiencies and problems of all kinds from individual neglect and abuse to systematic understaffing, poor working conditions and widespread inadequate and inhumane treatment, at some point, the quality of management is identified as a key factor causing the strife, and hence better management is proposed as a solution to the crisis (eg Räsänen, 2011; Hoppania, 2015; Hoppania et al, 2017). However, very little public debate has emerged about what (good-quality) care management actually entails. How, precisely, can management solve the acute problems in the quality of care and care work? Why do the crises of care persist, after years of intensive efforts to resolve them by improvements in management? This chapter approaches these questions by bringing the recent research on management trends in elderly care into dialogue with theories of the logic and rationality of care.

The chapter begins by discussing management trends in the care sector since the 1980s to 1990s. While many of these trends are global, the discussion focuses on the Nordic countries and Finland in particular, with an empirical focus on home care and institutional elderly care. Firstly, a brief discussion is provided of the historical context in which management has emerged as a key target of political intervention. The political arguments are highlighted via which managerialism, as a belief 
and value system that stems from the world of business and production rather than reproduction, has emerged as the driving ideology in the reform of elderly care in Finland and beyond.

Secondly, the chapter explores two prevailing trends of management as they have emerged in elderly care in Finland. Drawing on Hanne Marlene Dahl (2009), the discussion distinguishes between the predominantly rationalistic logic of details as a systemic logic that shapes the structures of care provision, and the more normative logic of self-governance as an affectively appealing discourse that offers emotionally engaging subjectivities and (often false) optimism to floor-level care management in various organisations. These trends have been the object of care research to an extent, notably in the work of Dahl (2009, 2012; also, Hoppania et al, 2017; Olakivi, 2018; Hirvonen et al, 2020), and in a number of empirical case studies discussed in this chapter. The contribution to the existing literature is to examine these two sides of managerialism explicitly in light of the logic of care (Mol, 2008).

The logic of care focuses on the needs of the individual and on care relationships. Since care needs are situational and temporal, they are seldom similar even for individuals of the same age and with the same illness. Instead, care needs vary even for the same person at different times. The production of care differs from, say, the production of cars and toothbrushes. This creates evident complications in the context of increasingly marketised care, including in Finland where private companies have dramatically increased their share of care provision during the past three decades (Karsio and Anttonen, 2013; Kröger, 2019). The marketisation of care, together with the increasing influence of business consultants in public service provision (Hirvonen et al, 2020), has also shaped publicly owned care organisations by introducing management styles that are imitating industry and business. These managerial styles have influenced the work of women in particular, who comprise a great majority of care workers all over the world. Men, in turn, are over-represented in the higher echelons of managerial hierarchies, also in the care field (Adams, 2010; Hussein et al, 2016). 
After discussing the different trends of management in light of the logic of care, the chapter returns to the socio-political context of the care crisis and the pitfalls of managerialism that have been exposed. Neither of these management styles sufficiently respect the logic of care, and at worst they contribute to the production of new crises. Moreover, it appears that the political focus on management obscures the root cause of the care crisis: the under-resourcing and undervaluing of gendered and embodied professional care work.

\section{Quality and efficiency through management?}

According to Kröger (2019), a demographic panic has been driving Finnish care policies, and governments have put a great deal of effort into avoiding their constitutional responsibility to serve the care needs of older adults. The avoidance of this responsibility has predominantly been implicit, with little open political discussion about the responsibilities of care, before the supervising bodies closed care homes and media coverage became widespread in 2019 (Hoppania, 2015). Incremental changes, such as more stringent needs testing and rises in client fees have led to complicated service systems and difficulties in accessing services. The politics of avoidance have created a situation in which family members need to shoulder heavier responsibilities than before, and the numbers of reports and complaints about inadequate care have increased dramatically, especially since 2019 (AVI, 2020). Another crisis is located within care work, characterised by staff shortages and employees’ psychophysical overload (Kröger et al, 2018).

Public debate and policy routinely offer better management as a solution to the crises (for example, STM, 2017). The alluring idea is that good management limits the need for economic investments in public care provision (Hoppania, 2015). This argument was strong even in the 1980s and 1990s during the first wave of New Public Management (NPM) that made the management of service provision a key target of political intervention (Henriksson and Wrede, 2008; Hoppania et al, 2016). 
In practice, NPM entailed management styles and tools from the private sector and businesses being implemented in the public sector, including in the provision of elderly care (Trydegård, 2012). NPM has been an international project, where ideas have travelled across countries and sectors. As a result, care work management in Finland and beyond has borrowed management styles, for example, from Japanese car factories (Lean Management), the US navy (Total Quality Management) and big business (Balanced Scorecards) with diverse results (Trydegård, 2012; Hirvonen et al, 2020).

NPM has been infused with high hopes, but also criticised (Diefenbach, 2009). According to critics, the constant focus on the development of management has diverted attention away from other targets of development, such as inadequate staff ratios and the fact that people with intensive care needs are increasingly forced to live at home. Indeed, the question about sufficient resources has typically been sidelined in elderly care policy reforms, even if it has somewhat paradoxically been the driving force behind those reforms (Hoppania, 2015). This might be changing now in Finland, at least to some extent, as in 2020 the parliament committed to raising staff ratios in care homes albeit only gradually and excluding home care services. Nevertheless, research suggests that currently the Finnish care system is in 'a situation where, as a result of both individual and structural issues, [older] people in need of care do not receive sufficient assistance from informal or formal sources, and thus have care needs that remain uncovered' (Kröger et al, 2019, p 3). In comparison to the level of funding for elderly care services in other Nordic countries, Finland is over one billion euros short annually (Seppälä, 2019). When public officials responsible for elderly care in the municipalities were asked about the sufficiency of home care, nearly one in two (46 per cent) replied that there are not enough home care services (THL, 2018). Clearly the enduring political focus on the development of care management has not solved these problems in Finland. 


\section{The diversifying toolbox for managing care work}

Managerialism refers to a broad ideology of industrialised societies according to which problems in almost any area of society can be effectively resolved via managerial interventions (Räsänen and Trux, 2012, p 45; Klikauer, 2015). Managerialism can be seen as an ideology whereby the world gets better when it is put into the hands of specialised managers (Räsänen and Trux, 2012, p 42). The aim is to control people and issues and ignore what cannot be controlled. From a managerialist perspective, moreover, management is a specific job, a profession requiring specific training and skills (Grey, 1999). Managerial skills are specific, but they allegedly apply to any field of work. As Thomas Klikauer (2015, p 1107) writes: 'Managerialism's perilous central doctrine is that differences between a university and a car company are less important than their similarities and that the performance of all organisations can be optimised by the application of generic management skills and knowledge'. Resisting managerial interventions, and interventions by business consultants promoting the latest trends of managerialism, may be particularly difficult for female-dominated service occupations, including elderly care work, compared to male-dominated fields, such as medicine (Hirvonen et al, 2020).

In Finland, care work managers (including leaders, supervisors and middle managers) are still expected to have specific training for care work and not only for management. However, management has become a new and independent field of expertise and a target for development and improvement in care work. Hence, while managers aim to manage care work, the work of managers is a target of management as well. New management styles, models, ideals and structures are developed continuously - and care work managers are expected to develop themselves accordingly. The turn to managerialism is a relatively recent one in care work in Finland. During the heyday of Nordic welfare state politics (1970-90), Finnish care politics placed a relatively strong emphasis on 
professional - instead of managerial - ideals and ethics of care provision (Henriksson et al, 2006). According to the professional ideals, care workers and their supervisors should have a relatively highly specialised and formal education in care work and their activities should primarily follow professional ethics of care (Paasivaara, 2002). These ideals have by no means lost their power in Finland: legislatively, care workers and their supervisors are still required to have formal education in care (Act on Qualification Requirements for Social Welfare Professionals, 272/2005). In comparison to other Nordic countries, Finnish care workers have the highest educational levels (Kröger et al, 2009). Since the early 1990s, however, political debates in Finland have become increasingly critical of professionalism in care (Henriksson and Wrede, 2008). Critical arguments have depicted professional care systems as old-fashioned, self-serving, economically inefficient, inflexible and not transparent enough (Henriksson and Wrede, 2008). To solve these problems, critics routinely call for better management. The increasing marketisation of care, and the respective diversification of public and private care providers, has only increased the calls for transparency and managerial control (eg Sitra, 2018).

Political and public calls for transparency, flexibility, efficiency and quality can be difficult to object to (Dahl, 2012). Yet care workers and academic commentators have criticised managerial transformations, especially transformations that imitate a specific style of management: the industrial and Taylorist model of standardised work processes, hierarchical planning, and formalised surveillance and control systems of care workers, originally developed for factory work management (Dahl, 2009; Diefenbach, 2009).

Contemporary working life idealises innovations, flexibility and self-governing employees - in contrast to Taylorist standardisation. While few nowadays openly advocate Taylorism in elderly care management, a number of Taylorist management tools have been implemented in care work since the 1990s. These include the obligation of care workers to constantly document and report on 
their work - an obligation that has been resisted by care workers since the 1990s (Paasivaara, 2002). Another Taylorist tool is the creation of quasi-markets within public care production, including the idea according to which care provision can be disintegrated into standardised, measurable and statistically comparable products and routines that care workers - especially in home care - perform by following pre-planned timetables and to-do lists (Heikkilä et al, 2014). These practices draw on an industrial management ideology that Dahl (2009) calls the logic of details.

The logic of details also implies new divisions of labour in care work. Professionals in leadership roles are increasingly expected to act as specialised managers in charge of the detailed control of their staff members' performance - rather than as experienced seniors who offer guidance to their junior colleagues (Bolton, 2005; King, 2012). This division of labour mitigates the importance of professional care work skills, education and specialisation both among managers and frontline workers. Instead of skilled professionals, the logic of details requires a flexible, compliant and controllable workforce willing to work according to the instructions and timetables planned by higher-level managers (Henriksson et al, 2006). To increase flexibility, a shorter educational path to the most routinised jobs in elderly care work has been established under the title of care assistant in Finland (Sinervo et al, 2013). This division of labour enables high turnover rates in care: if care workers mainly follow timetables and plans imposed on them by others, and require less work expertise and experience, they become increasingly replaceable. Often employers find such replaceable care workers among migrants and racialised minorities, especially in the metropolitan region of Helsinki (Näre, 2013; Olakivi, 2019). In Helsinki, 24 per cent of care assistants were foreign-born in 2016 (Statistics Finland, 2019). The proportion of foreign-born care assistants has more than tripled from 2004 (7 per cent), while the proportion of foreign-born care managers has remained close to zero (Statistics Finland, 2019). 
The Taylorist logic of details is not the only trend of Western managerialism in contemporary societies (Miller and Rose, 2008). Taylorist management has also become a common target of critique in care work (Gilbert, 2005; King, 2012). Managerialism has had to constantly renew itself and seek new legitimacy. Compared to the Taylorist principles of standardisation, hierarchy and external control, prevailing managerial trends tend to highlight almost opposite values, such as innovation, flexibility and employees' internal control (Boltanski and Chiapello, 2005). In recent decades, such managerial ideals and arguments have, to a degree, travelled from business and industrial management to public service provision (O'Reilly and Reed, 2010). In line with Dahl (2009), this chapter argues that these managerial trends draw on the logic of self-governance.

The logic of self-governance expects care workers to be responsible, autonomous, proactive, selfsteering and reflexive agents who constantly develop themselves, solve problems in their organisational environments and get things done - regardless of burdensome and precarious working conditions (Moffatt et al, 2014; Olakivi, 2017). The logic of self-governance expects care work managers, in turn, to activate and empower the above qualities in their subordinates. Instead of hierarchical controllers of the Taylorist model, care work managers are expected to act as inspiring leaders (O’Reilly and Reed, 2010), facilitators (du Gay et al, 1996), motivational coaches (Oldenhof et al, 2016), or 'enterprising co-ordinators of care' (Bolton, 2005, p 8), who influence their subordinates via subtle human resource management techniques (such as performance appraisal interviews and the articulation of 'organizational values').

Theoretically, the logic of self-governance sits well with the traditional, professional ideals of Finnish welfare state politics. While there is a clear conflict between professional ideals and the Taylorist logic of details, the logic of self-governance, to a degree, aligns with the professional ideals of internal devotion, responsibility and constant development (O'Reilly and Reed, 2010; Olakivi and Niska, 2017; see also Baagøe Nielsen in this volume). The logic of self-governance 
can, however, also impose novel expectations on care workers and their managers: instead of highlighting formal and specialised education, professional traditions and collective responsibility, the logic of self-governance highlights generic creativity, learning by doing, and the constant comparison of individual workers with respect to their personal performance and productivity (Moffatt et al, 2014; Olakivi, 2017).

Both lines of care work management, the logic of details and the logic of self-governance, are associated with the neoliberal politics of public welfare provision (Dahl, 2009). Whereas the logic of details highlights hierarchies and external standardisation, the logic of self-governance highlights another aspect of the neoliberal project (Miller and Rose, 2008; Baines et al, 2012): individual responsibility and constant self-development. In Finnish private and public sectors, publicly funded development projects according to the logic of self-governance have gained economic and ideological support since the 1990s (Arnkil, 2004; Hirvonen et al, 2020).

However, the growing appeal of the logic of self-governance has not led most care organisations to abandon the logic of details. Rather, care organisations have adopted some of the ideals of selfgovernance alongside the prevailing logic of details and the ideals of external control, disintegration and fragmentation. Many care organisations continue to implement information technologies and relatively faceless systems of reporting, recording and monitoring as management tools for streamlining processes by comparing separate units' performance statistics (Ahosola and LummeSandt, 2019). Respectively, the same organisation can have a number of middle managers and lower-level supervisors (ward managers, head nurses, home care supervisors) who have little control over the top-level management systems and technologies (Björk et al, 2013). The main task of these supervisors and middle managers is to coach, inspire, motivate and activate their subordinates' commitment, attitudes and values, and abilities to govern themselves and manage their jobs regardless of the Taylorist system (Antonsson, 2013). In this task, the discourse of self- 
governance can offer middle managers affectively appealing resources, tools and subjectivities but it can also create novel conflicts between care workers and their supervisors.

\section{The logic of care and the limits of detailed control}

Care is a particular kind of practice that follows the logic and rationality of care (Waerness, 1984;

Mol, 2008). The logic of care means that - unlike on the factory floor, or in clearly defined service products such as haircuts - the needs that require a response can change rapidly and unexpectedly. Care involves a human relationship in which the response of the one receiving care plays a part (Fisher and Tronto, 1990; Anttonen and Zechner, 2011). Care, at least good care, is an ongoing process including the caregiver and care receiver rather than a defined service product (Mol, 2008; Zechner, 2008).

The starting point in care work is always the need for care, not choice or want. In professional care work, the worker has to recognise and understand the kind of care that is required in a particular situation, and also to respect the autonomy of the person in need of care. Care is always about bodily, corporeal relationships. Individual caring situations are indirectly affected by a complex network and history of care relations. The personal (care) histories of the caregiver and the care receiver affect the situation and both parties' experiences of it (Valokivi and Zechner, 2009; Hoppania et al, 2016).

Paying attention to the bodily dimension of care illustrates the psychic and material limits of care management (Twigg et al, 2011). One can never be certain how a body will respond to care. Similarly, since care is relational work, the cognitive and emotional responses of both the person in need of care and the care worker vary (King, 2012). Care is always unpredictable to an extent, and therefore care work that follows the logic of care requires sensitivity and the ability to respond to changing situations. Hierarchical attempts to standardise and control care in line with the logic of 
details cause problems precisely due to this logic's incompatibility with the logic of care (Hoppania and Vaittinen, 2015).

A key source of conflict between the logic of details and the logic of care derives from time use. Implementing economic rationalisation in care work that ontologically resists standardisation is bound to make conceptions of time collide. The Taylorist logic of details gives care workers few opportunities to adjust their work rhythms to the changing situations (Astvik and Melin, 2012). For example, defining and standardising the amount of time that particular tasks for the recipients of care - such as eating, bathing, giving medication - should take, a common practice especially in home care in Finland, ignores the logic of care and the unpredictable nature of care situations. This can decrease both the quality of care and care workers' wellbeing and satisfaction, as care workers' abilities to follow the ethics of care dramatically decrease (Hirvonen and Husso, 2012). When managerially standardised time frames of work conflict with the actual time frames of care, a further danger is that the workers' needs - that is, their needs to satisfy their employers but also to take care of their own wellbeing in precarious working conditions - start to compete with the needs of the recipients of care (Sipiläinen et al, 2011). In Finnish home care, 39 per cent of employees state that in order to get their work done, they need to contravene the principles or rules of the workplace (Vehko et al, 2017).

According to a common argument, the logic of details pursues both economic efficiency and also quality of care. In this view, the quality of care improves if organisations have more control over the services they offer, by monitoring the performance and time use of care workers and the conditions of the recipients of care, and by collecting detailed information that higher-level managers and experts can quantify and statistically compare. These practices of rational-technical (Trevithick, 2014) quality control effectively ignore the everyday experience and professional 
knowledge of care workers, and also of middle managers and lower-level supervisors, in favour of higher-level management, numerical data and controlled methods.

Numerical data can, of course, be useful when different units and care organisations are compared. Ideally, numerical data can uncover real problems and highlight successes in the quality of care. It is, however, far from self-evident that numerical data can measure all aspects of the quality of care and the actual, situationally changing needs of the care recipients (Kurunmaki et al, 2016). In Finland, the long-lasting interest in numerical quality control has not prevented recurring crises. At worst, the logic of details can create separate realities: one in the everyday life of care, practical needs and encounters, another in the systems of higher management in which the recipients of care as well as care workers are reduced to numbers that are managed from a distance (Hoppania et al, 2016).

Finally, continuous reporting and monitoring of care absorbs time from actual care work. According to a recent study from Finland (Kröger et al, 2018), the proportion of elderly care workers that considered that documentation consumed too much of their working time grew from 38 per cent in 2005 to 70 per cent in 2015 . Paradoxically, the tool that was meant to control the quality of care can duly become an impediment to good care (Banerjee, 2013).

Organisations and service systems can tackle the above problems if they start to understand care as a human relationship and professional work that follows the ethics and logic of care. Consequently, the possibilities of management appear in a different light: what is central to management and policy making is to create conditions that enable work practices in line with the logic of care where individual and situational needs for care direct the organisation of care work. To enable this, care workers must have professional ethics and skills, including formal education, and practical abilities to form lasting relationships with their care recipients. Lasting relationships are a precondition for 
care workers to be able to recognise situational changes in the needs of the recipients of care. Growing turnover rates in elderly care work hamper this precondition. Finally, care workers must have practical resources - that is, time - to respond to the care recipients' situational, changing and unpredictable needs.

\section{The logic of care and the limits of self-governance}

In the 2020s, the inadequacy of Taylorist management is relatively well acknowledged in Finland among care workers, academics and also among middle managers and lower-level supervisors in old age care. The ways in which middle managers and care work supervisors understand and talk about good care often follow the logic of care instead of the logic of details (Stenman et al, 2015). These understandings highlight the importance of respecting older persons' individual needs and the need to invest time in the interaction between care workers and the recipients of care (Surakka et al, 2014, p 225-6). How middle managers can progress from appreciating the logic of care discursively to supporting it in practice is, however, another question.

In care work organisations, middle managers inhabit a difficult position. If the larger structural systems of care follow the Taylorist logic of details, and if middle managers lack the power to transform these structures, their options are limited. Yet managerial discourses expect middle managers to have an impact on care, and these discourses are normatively compelling (Olakivi, 2018). Middle managers can find the subjectivities enabled by the logic of self-governance affectively appealing and empowering (Olakivi and Niska, 2017). Instead of transforming the external systems of care work organisation - that may seem impossible - managers can conceive of themselves as inspiring leaders and motivational coaches (O'Reilly and Reed, 2010; Oldenhof et al, 2016; Hirvonen et al, 2020). They can activate their subordinates in becoming more responsible and independent actors able to proactively and dynamically respond to the care recipients' unpredictable 
needs, regardless of the Taylorist structures. In an article by Olakivi and Niska (2017), a head nurse in a Finnish public sector care home described her work, as a 'coach', as follows: "What I find most difficult is maybe giving negative feedback, or if we have to give warnings. That's not nice. I prefer being like a coach. So that I support and try to find a way so that the people will find the right way to act and find their own strengths, and that way support the functions as well."

The logic of self-governance seems to offer new optimism for care work managers. According to the optimist ideal, care work managers do not have to force their subordinates to act against the ethics of care. Instead, they can coach their subordinates to serve these ethics, but in alignment with more distant (and less visible) socio-political and economic objectives (Hirvonen et al, 2020) - that is, the political objective to avoid economic investments in the material conditions of care work. This management style aims to translate the objectives of employers and policy makers - better economic efficiency - into projects more easily acceptable to care workers - better quality of care and constant self-development (Moffatt et al, 2014). Simultaneously, the care worker is detached from their social relationships and brought under the managerial gaze as an individual target of intervention, with individual values, emotions and self-management abilities as targets of development. In the above article by Olakivi and Niska (2017), a home care supervisor discussed elderly care work, its burdens, and her own reactions to these burdens, as follows: 'It's a bit like you either like it [care work] or you don't. So in my opinion, when people always talk about the rush, the rush is a bit self-imposed [by care workers], so that sometimes you even have to stop people and go, like, "Hey, would you just sit down and see that it's not really that bad after all".'

Solving problems in care work via the logic of self-governance is not easy. Firstly, care organisations' support for employees' self-governance often seems superficial. If the structures of care continue to be organised according to the Taylorist logic of details, and if care workers are not granted the actual autonomy to decide how they organise their daily work, or the education and 
experience to enable such decisions, expecting care workers to govern themselves may appear to be a tall order - or simply another form of exploitation (Olakivi, 2018). Care workers are mainly given the autonomy to decide how they navigate through the plans, timetables and obligations imposed on them by others (Boyd, 2002). Supporting self-governance turns into supporting care workers' sense of responsibility, not their autonomy. If these techniques of coaching and activation are successful, care workers begin to accept individual responsibility for solving problems that their employers have caused, such as understaffing. The logic of self-governance does not change the logic of details, but merely downplays care workers' abilities to object to it. Similarly, middle managers who draw attention to structural problems in their work environment are stigmatised as unable to manage, coach and activate their staff members.

Even if care workers are granted real autonomy and the ability to decide how they organise their daily work, this does not self-evidently help. If the real problem is understaffing and a lack of resources, care workers' increased autonomy does not resolve the problem. In a recent Finnish study, having autonomy in daily work did not decrease care workers' intentions to leave their jobs (Olakivi et al, 2020). In the prevailing management discourse, however, self-governance tends to attract more attention than, for example, understaffing. Self-governance appears as something that middle managers and care workers can (and normatively should) cultivate, while understaffing appears to be out of their control.

The logic of self-governance pressures both care workers and middle managers who become responsible for solving care problems by supporting their subordinates' abilities to govern themselves. The logic of self-governance easily engenders interaction conflicts between care workers and their supervisors - between two female-dominated groups, neither of which are responsible for the prevailing care crises. If a supervisor is responsible for supporting her subordinates' abilities to govern themselves but the subordinates feel that the real problem in care is 
not their self-governance but the lack of resources, conflicts are likely to emerge (Olakivi, 2018). In a recent survey from Finland, nearly half of care workers in home care felt that their supervisors did not take care workers' concerns about their work overload seriously (Erkkilä, 2018). Middle managers also face contradictory expectations. They are expected to have experience in the care field, to work near the frontline of care work while the major part of their working time is consumed by administrative tasks, financial responsibilities and constant recruitment in order to fill the gaps in their staff caused by high turnover (Antonsson, 2013, pp 163-5). They are expected to be motivational and inspirational leaders for their subordinates while, in real life, they may have very little working time to support and supervise their staff (Björk et al, 2013, p 269; Kröger et al, 2018). Instead of focusing on the (in)actions of business owners, policy makers and higher-level managers in the field of elderly care, the logic of self-governance thus focuses on care workers and their immediate supervisors, and engenders conflicts between them that burden the entire work community (Satka and Hämeenaho, 2015).

The logic of care also applies to care workers and their supervisors, who are in many ways vulnerable and dependent on each other, on their bodies, on social relations in and out of the workplace. These vulnerabilities and dependencies make care workers and their supervisors prone to various unpredictable, situationally changing needs deriving from work but also beyond it, including from family obligations. The argument according to which care organisations can resolve all problems by supporting care workers' self-governance overlooks such needs, vulnerabilities and dependencies (Hoppania et al, 2016). The logic of self-governance merely combines the unpredictability of care with a strong responsibilisation of care workers and their immediate supervisors. 


\section{Conclusion}

While the deficits and crises in elderly care are starker in Finland than in other Nordic countries, the changes in management as a primary solution to these crises have also been more common than in neighbouring Sweden, for example (see Anttila et al, 2018). The broad ideology of managerialism cannot be reduced to any one type of management. Indeed, critiques of any one style of management often only call for a different, allegedly better style of management, thus reinforcing the ideology of managerialism. This chapter has focused on how two styles of managerial intervention, the more rationalistic logic of details and the predominantly normative logic of selfgovernance, clash with the logic and rationality of care. The logic of details emphasises the division of care work into specific tasks, the measurement of outputs, and a hierarchical division of labour divided between planning and control on the one hand, and implementation on the other. The logic of self-governance focuses on motivating and activating workers' abilities to control and develop themselves. Common to both management styles is the fact that they overlook care workers' professional and experiential knowledge on care and, at least in the Finnish context, the material circumstances of care provision.

The logic of details constructs a vision of care divided into predefined outputs that are carried out by the care worker with limited participation in the planning of care, and with limited abilities to respond to unpredictable care needs. Here, the care relationship and the logic of care are not the centre of attention. Rather, the focus is on documentable, measurable and manageable outputs of care. The management of care diverges from care relationships and becomes a field of specialisation for professionals who have expertise in planning and in keeping statistics on care (Kantanen et al, 2015). This development has repercussions for individuals receiving care. While care workers balance between their specified work tasks and clients' wishes, clients have to content themselves with the norms laid down in a system-oriented manner (Andersson et al, 2004). 
Unlike the logic of details, which highlights external control, the logic of self-governance expects care workers to be internally motivated, entrepreneurial, and responsible for implementing good care, for constantly developing themselves, and for being efficient. If the employee fails, the logic of self-governance identifies problems in the worker's values, commitment, responsibility or ability to practise self-governance - and calls for managerial interventions to solve such problems. The task of the manager is to guide the employee in the right direction. The manager has to reassure the care worker that anything is possible with the right attitude - even and especially if this belief conflicts with the employee's experience. Here, as well as in the logic of details, the care worker's knowledge of the work is subjugated to the manager's knowledge. The normative logic of selfgovernance demands a lot from the manager who, due to their own work overload, may have limited abilities to support their subordinates.

The analysis of different management trends and their combinations from the logic of care perspective responds to the question of why care crises continue to occur even after decades of developing care management. Simply put, care is difficult to manage. While we do not intend to deny that elderly care would benefit from good management, our discussion has demonstrated that business-like management models are a poor fit for the realities of care work. Prevailing management styles that are in conflict with the logic and rationality of care can aggravate, not alleviate, care crises. Importantly, the political focus on management easily obscures the root causes of the crisis relating to the under-resourcing and undervaluing of gendered and embodied professional care work. As long as the political focus continues to downplay the fact that care is a labour-intensive sector and that good care can only be achieved with a sufficient number of valued and educated professional workers whose work is organised respecting the logic of care, crises will occur. 


\section{References}

Act on Qualification Requirements for Social Welfare Professionals 272/2005, Available from: www.finlex.fi/fi/laki/alkup/2005/20050272 [Accessed 26 March 2020].

Adams, T.L. (2010) 'Gender and feminization in health care professions', Sociology Compass. 4(7): 454-65. https://doi.org/10.1111/j.1751-9020.2010.00294.x

Ahosola, P. and Lumme-Sandt, K. (2019) 'Vanhustyön kehittämishankkeet vanhuspalvelujärjestelmän vastuita rakentamassa', Janus, 27(3): 228-45.

Andersson, S., Haverinen, R. and Malin, M. (2004) 'Vanhusten kotihoito kolmesta näkökulmasta: vanhukset, työntekijät ja johto integroinnin ja asiakaskeskeisyyden arvioijina', Yhteiskuntapolitiikka, 69(5): 481-94.

Antonsson, H. (2013) Chefers arbete i äldreomsorgen - att hantera den svårhanterliga omvärlden. Relationen mellan arbete och organisering, Linköpig: Linköpings universitet.

Anttila, T., Oinas, T.S. and Mustosmäki, A. (2018) 'Towards formalisation: the organisation of work in the public and private sectors in Nordic countries', Acta Sociologica, 62(3): 315-33. https://doi.org/10.1177/0001699318761782

Anttonen, A. and Zechner, M. (2011) 'Theorizing care and care work', in B. Pfau-Effinger and T. Rostgaard (eds) Care between Work and Welfare in European Societies, Houndmills: Palgrave Macmillan, pp 15-34.

Arnkil, R. (2004) 'The Finnish workplace development programme: a small giant?', Concepts and Transformation, 9(3): 249-78. 
Astvik, W. and Melin, M. (2012) 'Coping with the imbalance between job demands and resources: a study of different coping patterns and implications for health and quality in human service work', Journal of Social Work, 13(4): 337-60.

AVI (2020) 'Tiedotteet [bulletins] 2020'. Aluehallintovirastot [Regional State Administrative Agencies], Available from: www.avi.fi/web/avi/tiedotteet-2020 [accessed 23 March 2020].

Baines, D., Charlesworth, S., Cunningham, I. and Dassinger, J. (2012) Self-monitoring, selfblaming, self-sacrificing workers: gendered managerialism in the non-profit sector. Women's Studies International Forum, 35(5), 362-71. https://doi.org/10.1016/j.wsif.2012.07.002

Banerjee, A. (2013) 'The regulatory trap: reflections on the vicious circle of regulation in Canadian residential care', in G. Meagher and M. Szebehely (eds) Marketisation in Nordic Eldercare: A Research Report on Legislation, Oversight, Extent and Consequences, Stockholm: Stockholm University, pp 203-15.

Björk, L., Bejerot, E., Jacobshagen, N. and Härenstam, A. (2013) 'I shouldn't have to do this: illegitimate tasks as a stressor in relation to organizational control and resource deficits', Work and Stress, 27(3): 261-77.

Boltanski, L. and Chiapello, E. (2005) The New Spirit of Capitalism, London: Verso.

Bolton, S.C. (2005) “"Making up” managers: the case of NHS nurses', Work, Employment and Society, 19: 5-23.

Boyd, C. (2002) 'Customer violence and employee health and safety', Work, Employment and Society, 16(1): 151-69. 
Dahl, H.M. (2009) 'New Public Management, care and struggles about recognition', Critical Social Policy, 29(4): 634-54.

Dahl, H.M. (2012) 'Who can be against quality: a new story about home-based care: NPM and governmentality', in C. Ceci, K. Bjørnsdottir and M.E. Purkis (eds) Perspectives on Care at Home for Older People, New York: Routledge, pp 139-57.

Diefenbach, T. (2009) 'New Public Management in public sector organizations: the dark side of managerialistic “enlightment”, Public Administration, 87(4): 892-909. doi:10.1111/j.14679299.2009.01766.x.

Du Gay, P., Salaman, G. and Rees, B. (1996) 'The conduct of management and the management of conduct: contemporary managerial discourse and the constitution of the "competent" manager', Journal of Management Studies, 33: 263-82.

Erkkilä, S. (2018) “Jos tää meno jatkuu, meidän sydämet särkyy”: selvitys työstä kotihoidossa ja kotihoitotyön kehittämisestä 2018, Helsinki: SuPer ry.

Fejes, A. and Nicoll, K. (2012) 'Rhetorical activation of workers: a case study in neo-liberal governance', in P. Hager, A. Lee and A. Reich (eds) Practice, Learning and Change: PracticeTheory Perspectives on Professional Learning, Amsterdam: Springer, pp 167-81.

Fisher, B. and Tronto, J. (1990) 'Toward a feminist theory of caring', in E.K. Abel and M. Nelson (eds) Circles of Care, New York: Albany State University of New York Press, pp 35-62.

Gilbert, T.P. (2005) 'Trust and managerialism: exploring discourses of care', Journal of Advanced Nursing, 52(4): 454-63. 
Grey, C. (1999) "“We are all managers now"; "we always were": on the development and demise of management', Journal of Management Studies, 36(5): 561-85.

Heikkilä, R., Björkgren, M., Vesa, M., Viitanen, B., Laine, A., Taimi, K., Noro, A., Mäkelä, M., Asikainen, J., Sohlman, B., Hammar, T., Mäkinen, L., Andreasen, P. and Finne-Soveri, H. (2014) Asiakasryhmittelyyn pohjautuva tuotteistus RUG-III/18-luokituksen avulla. Kotihoito Tampereella, Helsinki: THL, Available from: www.julkari.fi/bitstream/handle/10024/116771/URN_ISBN_978952-302-309-3.pdf;jsessionid=29D7054A954B7CA193F4D34D6D1263E4?sequence=1 [Accessed 25 March 2020].

Henriksson, L. and Wrede, S. (2008) 'Care work in the context of a transforming welfare state', in S. Wrede, L. Henriksson, H. Høst, S. Johansson and B. Dybbroe (eds) Care Work in Crisis: Reclaiming the Nordic Ethos of Care, Lund: Studentlitteratur, pp 129-30.

Henriksson, L., Wrede, S. and Burau, V. (2006) 'Understanding professional projects in welfare service work: revival of old professionalism?', Gender, Work and Organization, 13(2): 174-92.

Hirvonen, H. and Husso, M. (2012) 'Hoivatyön ajalliset kehykset ja rytmiristiriidat', Työelämän tutkimus, 10(2): 119-33.

Hirvonen, H., Mankki, L., Lehto, I. and Jokinen, E. (2020) 'Ammatillinen toimijuus leanajattelussa', in J. Kantola, P. Koskinen Sandberg and H. Ylöstalo (eds) Tasa-arvopolitiikan suunnanmuutoksia. Talouskriisistä tasa-arvon kriiseihin, Helsinki: Gaudeamus, pp 234-61.

Hoppania, H.-K. (2015) Care as a Site for Political Struggle, Publications of the Department of Political and Economic Studies 25, Helsinki: University of Helsinki, Available from: 
https://helda.helsinki. /bitstream/handle/10138/157561/careasas.pdf?sequence=1 [Accessed 15 December 2016].

Hoppania, H.-K. and Vaittinen, T. (2015) 'A household full of bodies: neoliberalism, care and "the political"”, Global Society, 29(1): 70-88.

Hoppania, H.-K., Karsio, O., Näre, L., Olakivi, A., Sointu, L., Vaittinen, T. and Zechner, M. (2016) Hoivan arvoiset: vaiva yhteiskunnan ytimessä, Helsinki: Gaudeamus.

Hoppania, H.-K., Olakivi, A. and Zechner, M. (2017) 'Johtamisen rajat vanhushoivassa', in J. Kulmala (ed) Parempi vanhustyö: menetelmiä johtamisen kehittämiseen, Jyväskylä: PS-kustannus, pp 202-24.

Hussein, S., Ismail, M. and Manthorpe, J. (2016) 'Male workers in the female-dominated long-term care sector: evidence from England', Journal of Gender Studies, 25(1): 35-49. doi:10.1080/09589236.2014.887001.

Kantanen, K., Kaunonen, M. and Helminen, M. (2015) 'The development and pilot of an instrument for measuring nurse managers' leadership and management competencies', Journal of Research in Nursing, 20(8): 667-77.

Karsio, O. and Anttonen, A. (2013) 'Marketisation of eldercare in Finland: legal frames, outsourcing practices and the rapid growth of for-profit services', in G. Meagher and M. Szebehely (eds) Marketisation in Nordic Eldercare: A Research Report on Legislation, Oversight, Extent and Consequences, Stockholm: Stockholm University, pp 85-124.

King, D. (2012) 'It's frustrating! Managing emotional dissonance in aged care work', Australian Journal of Social Issues, 47(1): 51-70. 
Klikauer, T. (2015) 'What is managerialism?', Critical Sociology, 41(7-8): 1103-19.

Kröger, T. (2019) 'Looking for the easy way out: demographic panic and the twists and turns of long-term care policy in Finland', in T.-K. Jing, S. Kuhnle, Y. Pan and S. Chen (eds) Aging Welfare and Social Policy, Cham: Springer, pp 91-104.

Kröger, T., Leinonen, A. and Vuorensyrjä, M. (2009) Hoivatyön tekijät. Suomalainen hoivatyö pohjoismaisessa tarkastelussa, Jyväskylä: Jyväskylän yliopisto, Available from:

https://jyx.jyu.fi/bitstream/handle/123456789/47699/978-951-39-3691-

4.pdf?sequence $=1$ andisAllowed=y [Accessed 25 March 2020].

Kröger, T., Puthenparambil Mathew, J. and Van Aerschot, L. (2019) 'Care poverty: unmet care needs in a Nordic welfare state', International Journal of Care and Caring, 3(4): 485-500. doi:10.1332/239788219X15641291564296.

Kröger, T., Van Aerschot, L. and Mathew Puthenparambil, J. (2018) Hoivatyö muutoksessa: suomalainen vanhustyö pohjoismaisessa vertailussa, YFI julkaisuja, 6, Jyväskylä: Jyväskylän yliopisto, Available from: https://jyx.jyu.fi/bitstream/handle/123456789/57183/978-951-39-73728.pdf?sequence=1 [Accessed 25 March 2020].

Kurunmaki, L., Mennicken, A. and Miller, P. (2016) 'Quantifying, economising, and marketising: democratising the social sphere', Sociologie du Travail, 58(4): 390-402.

Miller, P. and Rose, N. (2008) Governing the Present: Administering Economic, Social and Personal Life, Cambridge: Polity Press. 
Moffatt, F., Martin, P. and Timmons, S. (2014) 'Constructing notions of healthcare productivity: the call for a new professionalism?', Sociology of Health and Illness, 36(5): 686-702. doi:10.1111/1467-9566.12093.

Mol, A. (2008) Logic of Care: Health and the Problem of Patient Choice, London: Routledge.

Näre, L. (2013) 'Ideal workers and suspects: employers' politics of recognition and the migrant division of care labour in Finland', Nordic Journal of Migration Research, 3(2): 72-81.

O'Reilly, D. and Reed, M. (2010) '"Leaderism": an evolution of managerialism in UK public service reform', Public administration, 88(4): 960-78.

Olakivi, A. (2017) 'Unmasking the enterprising nurse: migrant care workers and the discursive mobilisation of productive professionals', Sociology of Health and Illness, 39(3): 428-42.

Olakivi, A. (2018) The Relational Construction of Occupational Agency: Performing Professional and Enterprising Selves in Diversifying Care Work, Helsinki: University of Helsinki.

Olakivi, A. (2019) 'The problematic recruitment of migrant labor: a relational perspective on the agency of care work managers', Current Sociology, 68(3), 333-52.

doi:10.1177/0011392119837319

Olakivi, A. and Niska, M. (2017) 'Rethinking managerialism in professional work: from competing logics to overlapping discourses', Journal of Professions and Organization, 4(1): 20-35.

Olakivi, A., Van Aerschot, L., Mathew Puthenparambil, J. and Kröger, T. (2020) 'Ylikuormitusta, lähijohtajan tuen puutetta vai vääränlaisia tehtäviä: miksi yhä useammat vanhustyöntekijät harkitsevat työnsä lopettamista?', Yhteiskuntapolitiikka, accepted for publication. 
Oldenhof, L., Stoopendaal, A. and Putters, K. (2016) 'Professional talk: how middle managers frame care workers as professionals', Health Care Analysis, 24(1), 47-70. https://doi.org/10.1007/s10728-013-0269-9.

Paasivaara, L. (2002) 'Tavoitteet ja tosiasiallinen toiminta: suomalaisen vanhusten hoitotyön muotoutuminen monitasotarkastelussa 1930-luvulta 2000-luvulle', Oulu: University of Oulu, Available from: http://jultika.oulu.fi/files/isbn9514269012.pdf [Accessed 20 November 2020 ].

Räsänen, K. and Trux, M.-L. (2012) Työkirja: ammattilaisen paluu, Helsinki:

Kansanvalistusseura.

Räsänen, R. (2011) Ikääntyneiden asiakkaiden elämänlaatu ympärivuorokautisessa hoivassa sekä hoivan ja johtamisen laadun merkitys sille. Acta universitatis Lappoensis 210, Rovaniemi: Lapland University Press, Available from:

https://lauda.ulapland.fi/bitstream/handle/10024/61722/R\%C3\%A4s\%C3\%A4nen_Riitta_DORIA.p df? sequence $=4$ [Accessed 24 March 2020].

Satka, M. and Hämeenaho, P. (2015) 'Finnish eldercare services in crisis: the viewpoint of rural home care workers', Nordic Social Work Research, 5(1): 81-94. doi:10.1080/2156857X.2014.943265.

Seppälä, A. (2019) 'Huippututkija: miljardi euroa lisää vuodessa nostaisi Suomen vanhushuollon pohjoismaiselle keskitasolle', Yle, 30 January 2019, Available from: https://yle.fi/uutiset/310618988 [Accessed 24 March 2020].

Sinervo, T., Koponen, E-L., Syrjä, V. and Hietapakka, L. (2013) Hoiva-avustajaselvitys: joustava koulutus ja työllistymisväylä sosiaali- ja terveyspalveluiden avustaviin tehtäviin, Helsinki: STM, 
Available from: http://julkaisut.valtioneuvosto.fi/bitstream/handle/10024/70156/URN_ISBN_978952-00-3453-5.pdf? sequence=1andisAllowed=y [Accessed 25 March 2020].

Sipiläinen, H., Kankkunen, P. and Kvist, T. (2011) 'Kaltoinkohtelu vanhainkodeissa - hoitotyön johtajien käsityksiä altistavista tekijöistä ja ennaltaehkäisystä’, Gerontologia, 25(1): 15-26.

Sitra (2018) Ilmiömäinen julkinen hallinto: keskustelualoite valtioneuvoston toimintatapojen uudistamiseksi, Helsinki: Sitra, Available from:

https://media.sitra.fi/2018/09/03163806/ilmiomainenjulkinenhallinto.pdf [Accessed 25 March 2020].

Statistics Finland (2019) Labour statistics on foreign-born employees available on request from www.stat.fi.

Stenman, P., Vähäkangas, P., Salo, P., Kivimäki, M. and Paasivaara, L. (2015) 'Henkilöstön työtyytyväisyys vanhustenhuollossa - kohti kuntoutumista edistävän hoitotyön toimintamallin käyttöönottoa', Hoitotiede, 27(1): 31-42.

STM (2017) Laatusuositus hyvän ikääntymisen turvaamiseksi ja palvelujen parantamiseksi 20172019. Sosiaali- ja terveysministeriön julkaisuja 2017:6, Helsinki: Sosiaali- ja terveysministeriö, Available from:

http://julkaisut.valtioneuvosto.fi/bitstream/handle/10024/80132/06_2017_Laatusuositusjulkaisu_fi_ kansilla.pdf?sequence=1 andisAllowed=y [Accessed 24 March 2020].

Surakka, T., Suonsivu, K. and Åstedt-Kurki, P. (2014) 'Vanhustyön lähijohtajien näkemyksiä hyvästä vanhuksen kanssa tehtävästä työstä', Gerontologia, 28(4): 221-30. 
THL (2018) 'Vanhuspalvelujen tila', Helsinki: THL, Available from:

https://thl.fi/fi/web/ikaantyminen/muuttuvat-vanhuspalvelut/vanhuspalvelujen-tila [Accessed 25 March 2020].

Tiessalo, P. (2019) ‘Akuutti kriisi päällä, asiakasturvallisuus vaarassa hoivakoti Ulrikassa - kunta otti toiminnan vastuulleen', Yle, 26 January 2019, Available from: https://yle.fi/uutiset/3-10615577 [Accessed 20 March 2020].

Trevithick, P. (2014) 'Humanising managerialism: reclaiming emotional reasoning, intuition, the relationship, and knowledge and skills in social work', Journal of Social Work Practice, 28(3): 287-311. doi:10.1080/02650533.2014.926868.

Trydegård, G.-B. (2012) 'Care work in changing welfare states: Nordic care workers' experiences', European Journal of Ageing, 9(2): 119-29.

Twigg, J., Wolkowitz, C., Cohen, R.L. and Nettleton, S. (2011) 'Conceptualising body work in health and social care', Sociology of Health and Illness, 33(2): 171-88.

Valokivi, H. and Zechner, M. (2009) 'Ristiriitainen omaishoiva - läheisen auttamisesta kunnan palveluksi', in A. Anttonen, H. Valokivi and M. Zechner (eds) Hoiva - tutkimus, politiikka ja arki, Tampere: Vastapaino, pp 126-53.

Valvira (2019) 'Vanhustenhoivan epäkohtailmoituksia saatu runsaasti - jokainen otetaan vakavasti', Valvira, 6 March 2019, Available from: www.valvira.fi/-/vanhustenhoivan-epakohtailmoituksiasaatu-runsaasti-jokainen-otetaan-vakavasti [Accessed 15 May 2020].

Vehko, T., Sinervo, T. and Josefsson, K. (2017) Henkilöstön hyvinvointi vanhuspalveluissakotihoidon kehitys huolestuttava. Tutkimuksesta tiiviisti 11, Helsinki: THL, Available from: 
www.julkari.fi/bitstream/handle/10024/134678/URN_ISBN_978-952-302-876-0.pdf?sequence=1 [Accessed 25 March 2020].

Waerness, K. (1984) ‘The rationality of caring', Economic and Industrial Democracy, 5(2): 185211.

Yle (2006) ‘Tampereelle huomautus hoitajapulasta', Yle, 30 March 2006, Available from: https://yle.fi/uutiset/3-5224104 [Accessed 6 April 2020].

Zechner, M. (2008) 'Kykyjä kyvyttömyyden tasolla: hoivan vaiheet vanhusten kertomana', Janus, 16(4): 295-310. 